\section{Global Proceedings Repository \\ American Research Foundation}

ISSN 2476-017X

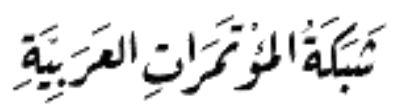

http://arab.kmshare.net/

Available online at http://proceedings.sriweb.org

The 1st International Conference on Sciences and Arts (ICMSA 2017)

$$
3 \text { المؤتمر الدولي الاول للعلوم والاداب } 2017 \text { - اربيل - العراق }
$$

http://sriweb.org/erbil/

\title{
Development of an Organizational Structure of the Department of Quality Control in Construction Companies
}

\author{
Alyaa Hammadi Mohsin (PhD.) $)^{a}$, Dunya Sahib Ellk \\ ${ }^{a}$ Civil Engineering Department, AL-Mustansiriyah University, Baghdad, Iraq \\ aliaahammadi@yahoo.com \\ ${ }^{\mathrm{b}}$ Roads \& Transportation Engineering Department, AL-Mustansiriyah University, Baghdad, \\ Iraq \\ dunia_eng@yahoo.com
}

\begin{abstract}
. construction projects is characterized by the fact that each project has a privacy and requirement differs from each other, this makes it difficult to establish a fixed solutions for all the problems facing the implementation of the project, so the process of quality control over the implementation of the project and completing it within the specified duration, cost, and quality has become the dream of all the workers in this sector. In this research an organizational structure for the work of the department of quality control in construction companies was proposed. The proposed organizational structure is based on scientific sources related to the subject and the questionnaire which has been conducted with consultants and experts in the field of the implementation of construction projects, the proposed organizational structure was applied to a project which has a deviation between actual and planned completion rates. The proposed system has proven its effectiveness through showing positive and clear results by reducing deviation in project duration during a short period of time.
\end{abstract}

Keywords: quality control, organizational structure, construction projects. 
ISSN 2476-017X

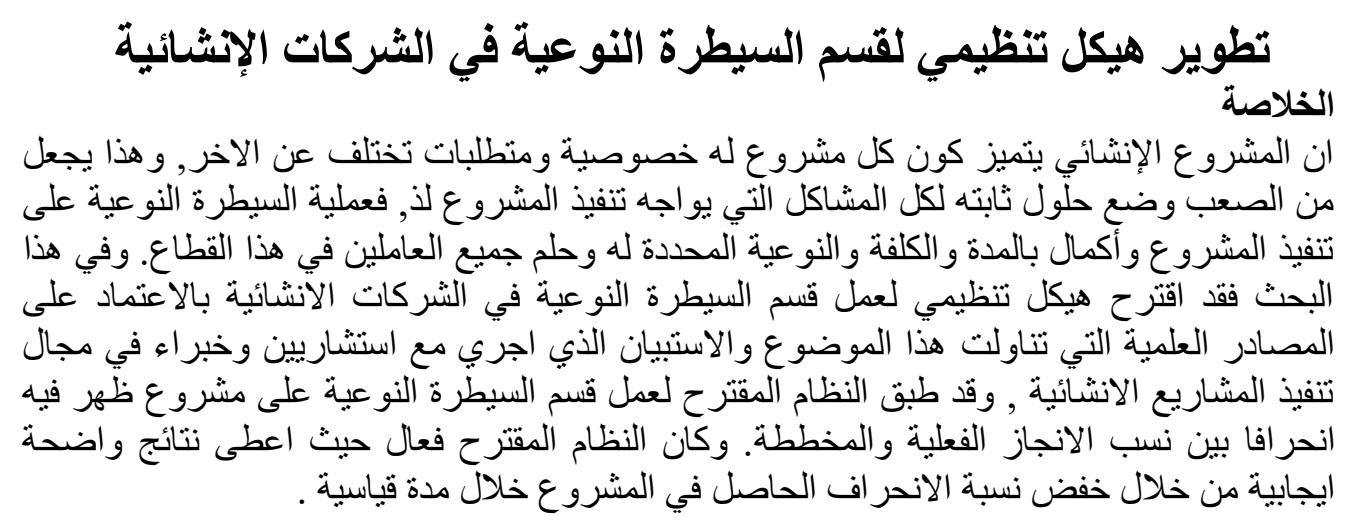

\section{Introduction}

The role of quality control department is in most construction companies, it is responsible of determining the percentage of completion of projects in order to pay and documenting the stops for future demands while modern management gives the quality control department much larger role through monitoring and treatment of projects problems which gives the opportunity to complete projects within the required time, cost and quality. Quality control department has a vital and sensitive role in construction projects. [1]

\section{Quality control for construction projects}

For construction projects, quality control means making sure things are done according to the plans, specifications, and permit requirements. The days of easy federal money seem to be over, making it imperative that communities get the most out of their infrastructure projects. One of the best ways to assure good construction projects is to use an inspector. The first step an inspector should take is to become familiar with the plans, specification, and permit requirements and, equally important, to have some common sense. Quality control during all construction phases needs to be better, and the utility system needs to know what is being installed while the work is being done. On most construction jobs, the inspection is one of the last things to be done-if it gets done at all. [2]

\section{Factors affecting construction project quality}

Establishing project requirements at the project inception stage could affect the quality of completed project. As [3] mentioned that, quality of any construction project is meeting the requirements of the designer, constructor and regulatory agencies as well as the owner. Accordingly, a careful balance between the owner's requirements of the project costs and schedule, desired operating characteristics, materials of construction, etc. and the design professional's need for adequate time and budget to meet those requirements during the design process is essential. Owners balance their requirements against economic considerations and, in some cases, against chance of failure [4]. The design professional is obligated to protect public health and safety in the context of the final completed project. The constructor is responsible for the means, methods, techniques, sequences, and procedures of construction, as well as safety precautions and programs during the construction process [4; 5]. The completion of project in accordance with the project requirements could be assured by the 


\section{Global Proceedings Repository American Research Foundation}

ISSN 2476-017X

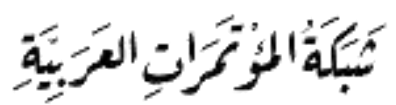

http://arab.kmshare.net/

Available online at http://proceedings.sriweb.org

quality of its construction. Project requirements are the key main factors influencing construction project quality. However, it can be influenced by many factors. According to a study by [6], management commitment and leadership in construction organizations could affect construction quality. It is because, the poor management practices directly and indirectly lead to decline of construction productivity and ultimately effect on project quality. In construction terms, cost, schedule, and possibly quality goals are established for each project. Project managers are rewarded on the basis of meeting these goals [7]. Further, the quality teams provide companies with the structured environment necessary for successfully implementing and continuously applying the quality in construction [6]. As [6] further stated, extent of teamwork of parties participating in the design phase was found to be the most important factor that affects quality teamwork among parties such as Structural Engineers, Electrical Engineers, Environmental Engineers, Civil Engineers, Architects, and owners is essential to reach the quality goals for design. Further, in the construction phase, extent of teamwork of parties participating in the construction process was found to be very important.

\section{The proposed organizational structure}

In this research an organizational structure has been proposed in order to develop the work of quality control department. The information that has been used in developing the proposed organizational structure was gotten from literature review and open interviews with engineers and consultants who have experiments in executing construction projects.

In order to develop the work of quality control department and ensure work accuracy especially in large projects which involve working in several items in different places of the project at the same time, it was proposed to divide quality control department into three divisions as explained in figure (1). Table (1) shows the duties of each of the three divisions.

Fig 1.the proposed organizational structure 
Available online at http://proceedings.sriweb.org

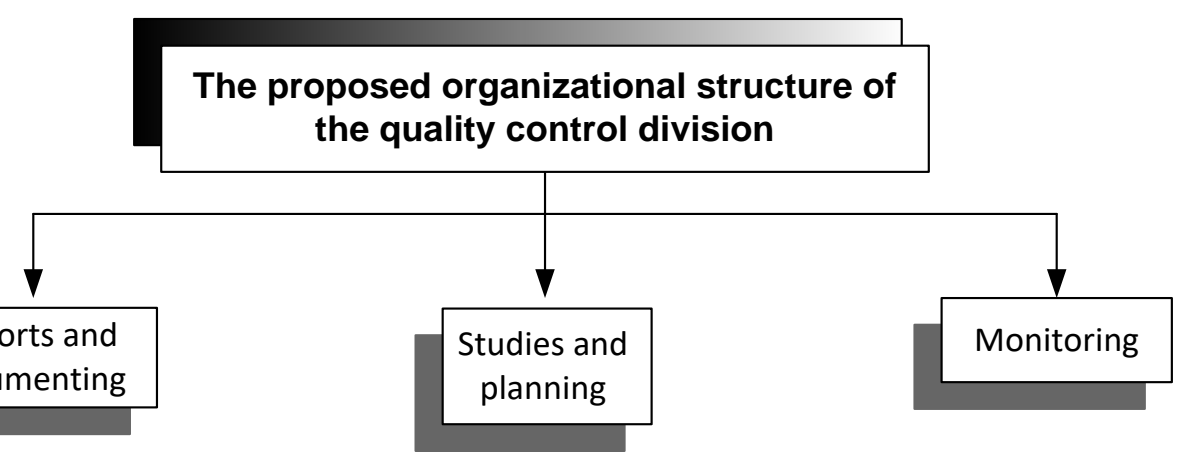

\begin{tabular}{|c|c|}
\hline divisions & Duties \\
\hline $\begin{array}{l}\text { Reports and } \\
\text { documenting }\end{array}$ & 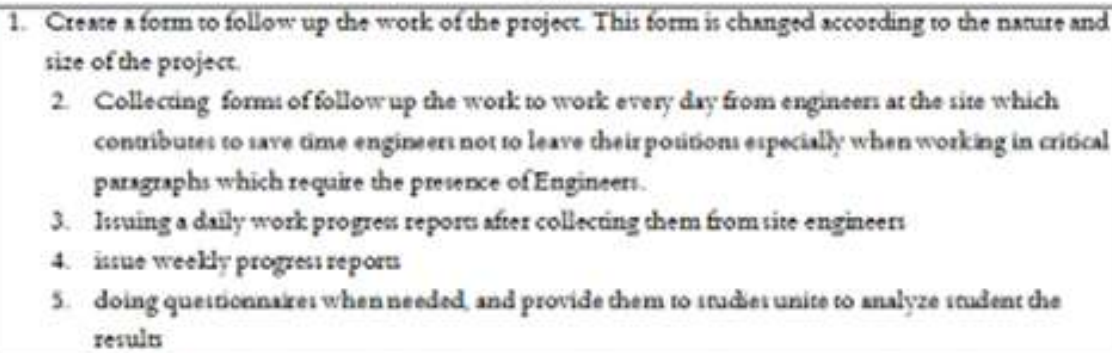 \\
\hline $\begin{array}{l}\text { Soudies and } \\
\text { planning }\end{array}$ & 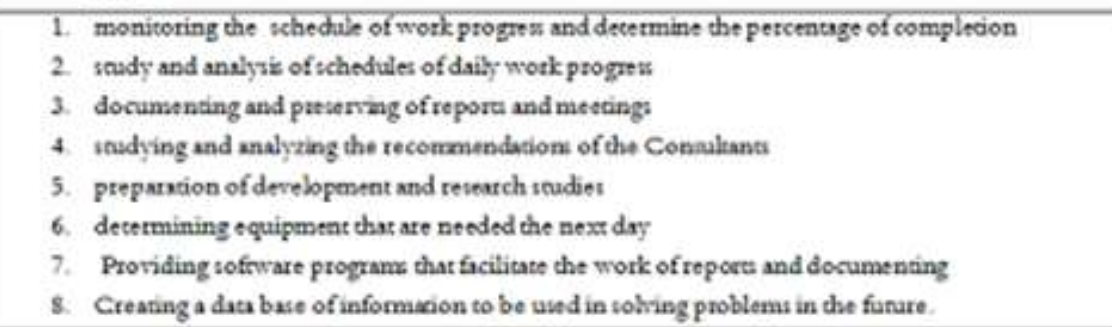 \\
\hline Monitoring & $\begin{array}{l}\text { 1. Monitoring incoming and outgoing Email with the comprevies and the relevant authoritiet } \\
\text { 2. pteparing and arranging meecings and seminar } \\
\text { 3. periodic meetings with the site enginets to discus what has been achiered and the obrtacles } \\
\text { fucing the workflow and the proposed plum for the next day }\end{array}$ \\
\hline
\end{tabular}

Table 1. duties of the department divisions 


\section{Global Proceedings Repository American Research Foundation}

ISSN 2476-017X

Available online at http://proceedings.sriweb.org

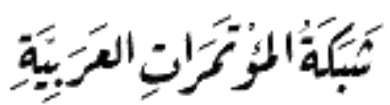

http://arab.kmshare.net/

\begin{abstract}
Alqaherah-UR Bridge as a case study
The bridge consists of a main body, which connects the end of Jafar-Sadeq University Street, from the side of Alqaherah neighborhood with Ur neighborhood through Al-Jaish channel, In addition to four sub-approaches with vertical axes on the main axis, linking the directions of all traffic on the main body to Omar bin Al-Khattab and Imam Ali highways, which are parallel to Al-Jaish channel.

Total duration of the project $=390$ days - duration of project contract $($ design + Execution).Total duration for the completion of key parts of the project $=307$ days. Number of actual working days for completion of key project parts $=3009$ days.
\end{abstract}

\title{
Applying the proposed organizational structure
}

The proposed organizational structure of the Department of quality control was applied in the company that executed the project. The Department of quality control consists of three Divisions as was been mentioned previously. The work of the three divisions is explained as the following:

\section{1. studies and planning division}

The main job of this division is organizing the work of the project; their duties can be summarized as the following:

a. Preparation of the planned time schedule of the project, which is the most complex studies, the most sensitive to changes in the field construction management. Planning time of construction projects overlap the four resources (4Ms: Man-Machine-Material-Money) which has a significant impact on the success of the planning process also the experience with the need to accommodate the planned potential of the implementing agency and the surrounding circumstances, whether internal or external .

b. In order to ensure the integrity of the work of Studies and Planning Division with other divisions in full control of the implementation of the project work; it was necessary to create an integrated information management system is closely linked to the timetable of the project, and included:

- Human Resources Management System

- warehouses and stores management system

- Fixed Assets System

The project was divided into 13 parts to facilitate preparing and monitoring of time schedules, each part was given a relative weight that was calculated from equation (1). Table (2) shows relative weights for all parts.

Table (3) explains actual Duration needed for each part, start and finish dates which can be determined according to activities involved in each part and productivity of workers and equipment. The finish date of the last part of the project will be the finish date of the project. 


\section{Global Proceedings Repository American Research Foundation}

ISSN 2476-017X

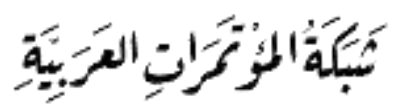

http://arab.kmshare.net/

Available online at http://proceedings.sriweb.org

Relative weight for each part $=\frac{\text { planned dutation }}{\text { planned total project dutation }}$

Table 2. relative weight of each part

\begin{tabular}{||c|c|c|}
\hline Parts & $\begin{array}{c}\text { Days of } \\
\text { work }\end{array}$ & $\begin{array}{c}\text { Relutive } \\
\text { weight }\end{array}$ \\
\hline LOT1 & 157 & 5.22 \\
\hline LOT2L & 167 & 5.55 \\
\hline LOT2R & 167 & 5.55 \\
\hline LOT3L & 364 & 12.10 \\
\hline LOT3R & 385 & 12.89 \\
\hline LOTAL & 167 & 5.55 \\
\hline LOT4R & 167 & 5.55 \\
\hline LOT5 & 119 & 395 \\
\hline LOT6 & 182 & 6.05 \\
\hline LOT & 162 & 5.35 \\
\hline LOT8 & 167 & 5.55 \\
\hline LOT9 & 162 & 5.35 \\
\hline LOT10 & 196 & 6.51 \\
\hline LOT11 & 157 & 5.22 \\
\hline LOT12 & 125 & 4.15 \\
\hline LOT13 & 162 & 5.35 \\
\hline & $\Sigma^{3009}$ & 100.00 \\
\hline \hline
\end{tabular}

Table 3. start and finish dates

\begin{tabular}{|c|c|c|c|c|}
\hline No. & $\begin{array}{l}\text { LOT } \\
\text { No. }\end{array}$ & $\begin{array}{c}\text { Starting } \\
\text { Date }\end{array}$ & $\begin{array}{c}\text { Durxtion } \\
\text { dayn }\end{array}$ & $\begin{array}{l}\text { Finish } \\
\text { Date }\end{array}$ \\
\hline 1 & 1 & $20,6 / 2005$ & 134 & $31 / 10 / 2005$ \\
\hline 2 & $2 L$ & $151 / 2006$ & 93 & $15: 5000$ \\
\hline 3 & $2 \mathrm{R}$ & $412 / 2005$ & 109 & $22,3 / 2006$ \\
\hline 4 & 31 & 1312006 & 101 & $25 / 4,2506$ \\
\hline 5 & SR & $131 / 2006$ & 99 & $21 / 42006$ \\
\hline 6 & $4 \mathrm{~L}$ & $4,22: 2005$ & 110 & $23 / 3 / 2006$ \\
\hline 7 & $4 \mathrm{R}$ & 1312006 & 92 & 14.42506 \\
\hline 8 & 5 & $27,6,2005$ & 113 & $17 / 10 / 20005$ \\
\hline 9 & 6 & 2562005 & 101 & $1211 / 2005$ \\
\hline 10 & 7 & $t 82006$ & 233 & 21322006 \\
\hline 11 & 8 & 9722005 & 134 & $1911 / 2005$ \\
\hline 12 & 9 & 692005 & 215 & 842006 \\
\hline 13 & 10 & 97,2005 & 149 & 412,2005 \\
\hline 14 & 11 & 1082005 & 223 & $18<2506$ \\
\hline 15 & 12 & 1812005 & 110 & 18112006 \\
\hline 16 & 13 & $30: 10 \cdot 2005$ & 144 & $22 / 3 / 3006$ \\
\hline
\end{tabular}

Determinants that affected the specified durations and start dates for the project parts are as follows:

a. The duration of implementing the project is very little (390 days only) as compared to the large design and the many details and difficult circumstance that cast a dark shadow on the implementation inevitably, thus, many activities have been reduced to minimal implementation time.

b. The start dates of implementing parts (LOTs) were identified on the basis of the conflicts existing in the site and considering the limited templates; with an emphasis on planning that 


\section{Global Proceedings Repository American Research Foundation}

ISSN 2476-017X

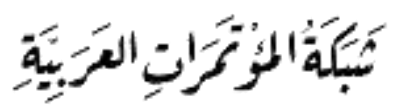

http://arab.kmshare.net/

Available online at http://proceedings.sriweb.org

takes into account the accumulation of experience achieved in executing parts in the latter part of the project.

c.Incidental or emergency conditions Which occur on site required starting with the six approaches in the middle part, Which led to linking the date of completion of approaches to the completion of the common axes between them and the central part of the bridge

The success of any system depends on two main factors: self-sufficiency and adequacy of employees working in; to ensure continuous sustain and feed it with the correct data to get accurate results.

\section{Reports and Documenting Division}

The main job of this division is to prepare reports and documenting the results. In order to apply quality control principles, Reports and documenting division duties were as follows:

a. Develop an information form filled daily by Executive engineers in the project as shown in figure (2) , and then answers gathered in one report (project progress report) as in figure (3).

b. Prepare questionnaires to evaluate certain situations in the project. For example a delay was accrued in the arrival of reinforcing steel to the project so that an assessment of metal workshop as it is one of the important sections in the project - as the project is a concrete bridge- was needed.

Reports and documenting division prepared a questionnaire to be filled by engineers in order to evaluate the work of metal workshop. The questionnaire results were analyzed by Studies and Planning Division; and the questions on the questionnaire evaluating the work of the workshop rebar steel as the follows:

1- Do you have schedule contain the amount and the type of the rebar steel which should be used in the site? The result answer is in fig. (4).

2-what is the period which submit request for the rebar steel from the workshop rebar steel? The result answer is in fig.(5).

3 -is the rebar steel arriving in time? The result answer is in fig.(6).

4-is the reason for the delay in providing you with a rebar steel delay work on your site? The result answer is in fig.(7).

5-is your submit request for the rebar steel from the workshop rebar steel contain provide rebar steel progressively or full amount? The result answer is in fig. (8).

6-your submit request for the rebar steel contain the size $(12,16,20,25,32 \mathrm{~mm})$ ? The result answer is in fig.(9).

7 -which type of the rebar steel delay providing when you required the size $(12,16,20,25,32$ $\mathrm{mm})$ ? The result answer in fig.(10).

According to questionnaire results the following actions were applied to avoid delay in material arrival:

- Preparing an information form to be filled by executive engineer a week before starting the work in that part of project as in figure(11), so that the metal workshop provide the needed amount of reinforcing steel with specified specifications

- Prepare another information form as in figure (12) to determine other resources that are needed for the work. This form must be applied a week before start date working in the intended part of project.

Fig 2. A form to be filled daily by execution engineers 
ISSN 2476-017X

Available online at http://proceedings.sriweb.org

\begin{tabular}{|c|c|c|c|c|c|c|c|c|c|c|c|}
\hline \multicolumn{12}{|c|}{ Table of quality control } \\
\hline \multirow[b]{2}{*}{ note } & \multicolumn{2}{|c|}{ Resources (materials) } & \multicolumn{2}{|c|}{$\begin{array}{l}\text { Resources } \\
\text { (Equipment) }\end{array}$} & \multicolumn{4}{|c|}{ Human Resources(No.) } & \multirow[b]{2}{*}{$\begin{array}{c}\text { Activity } \\
\text { description }\end{array}$} & \multirow[b]{2}{*}{$\begin{array}{c}\text { Activity } \\
\text { No. }\end{array}$} & \multirow[b]{2}{*}{ Seq. } \\
\hline & $\begin{array}{l}\text { Quantity } \\
\text { and unit }\end{array}$ & material & No. & equipment & worker & $\begin{array}{l}\text { Skilled } \\
\text { worker }\end{array}$ & foreman & Eng. & & & \\
\hline & & & & & & & & & & & \\
\hline & & & & & & & & & & & \\
\hline & & & & & & & & & & & \\
\hline & & & & & & & & & & & \\
\hline \multicolumn{12}{|c|}{ quality Eng. } \\
\hline
\end{tabular}

Fig 3. The daily progress report of the project 


\section{Global Proceedings Repository \\ American Research Foundation}

ISSN 2476-017X

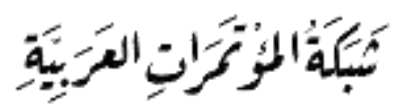

http://arab.kmshare.net/

ARF

Available online at http://proceedings.sriweb.org

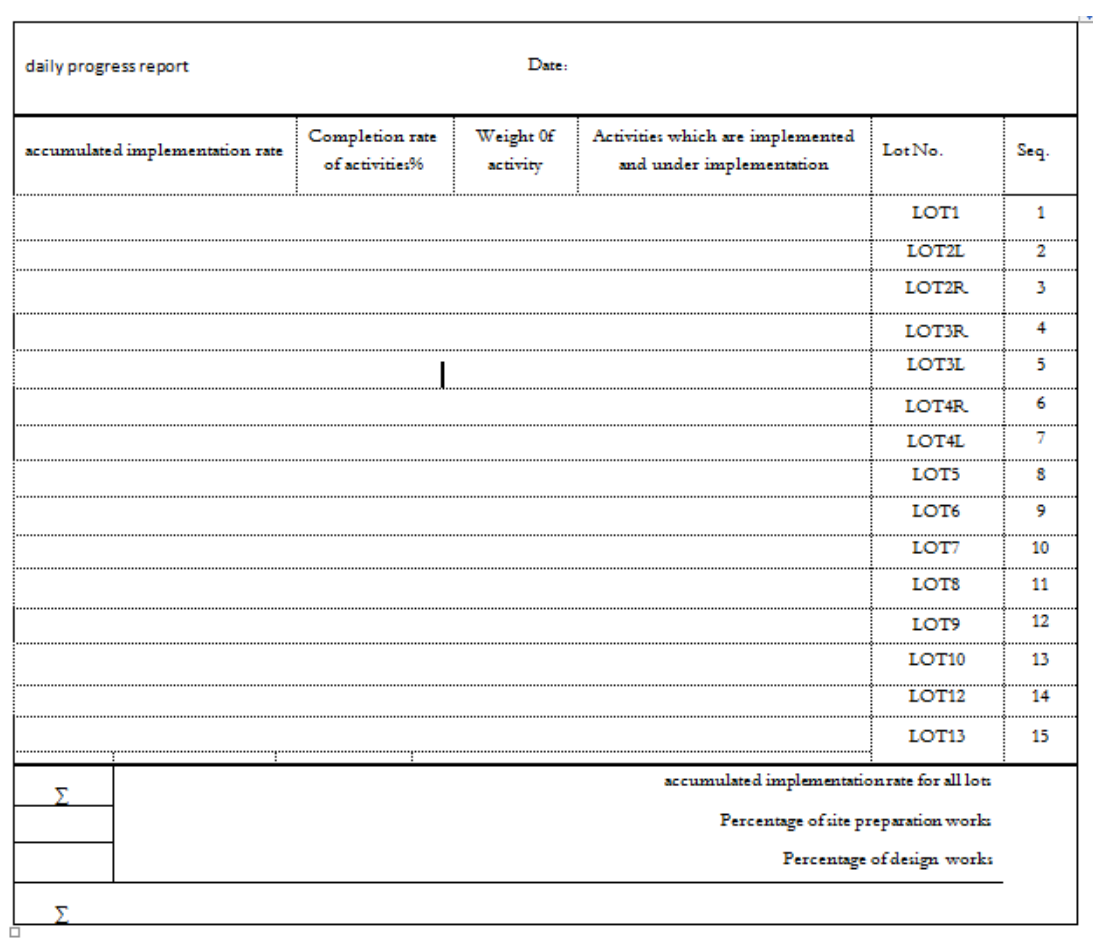




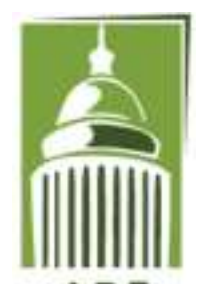

ARF

\section{Global Proceedings Repository American Research Foundation}

ISSN 2476-017X

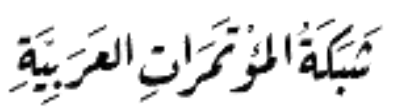

http://arab.kmshare.net/

Available online at http://proceedings.sriweb.org

Fig. from (4-10) are the results and explained of the questionnaire
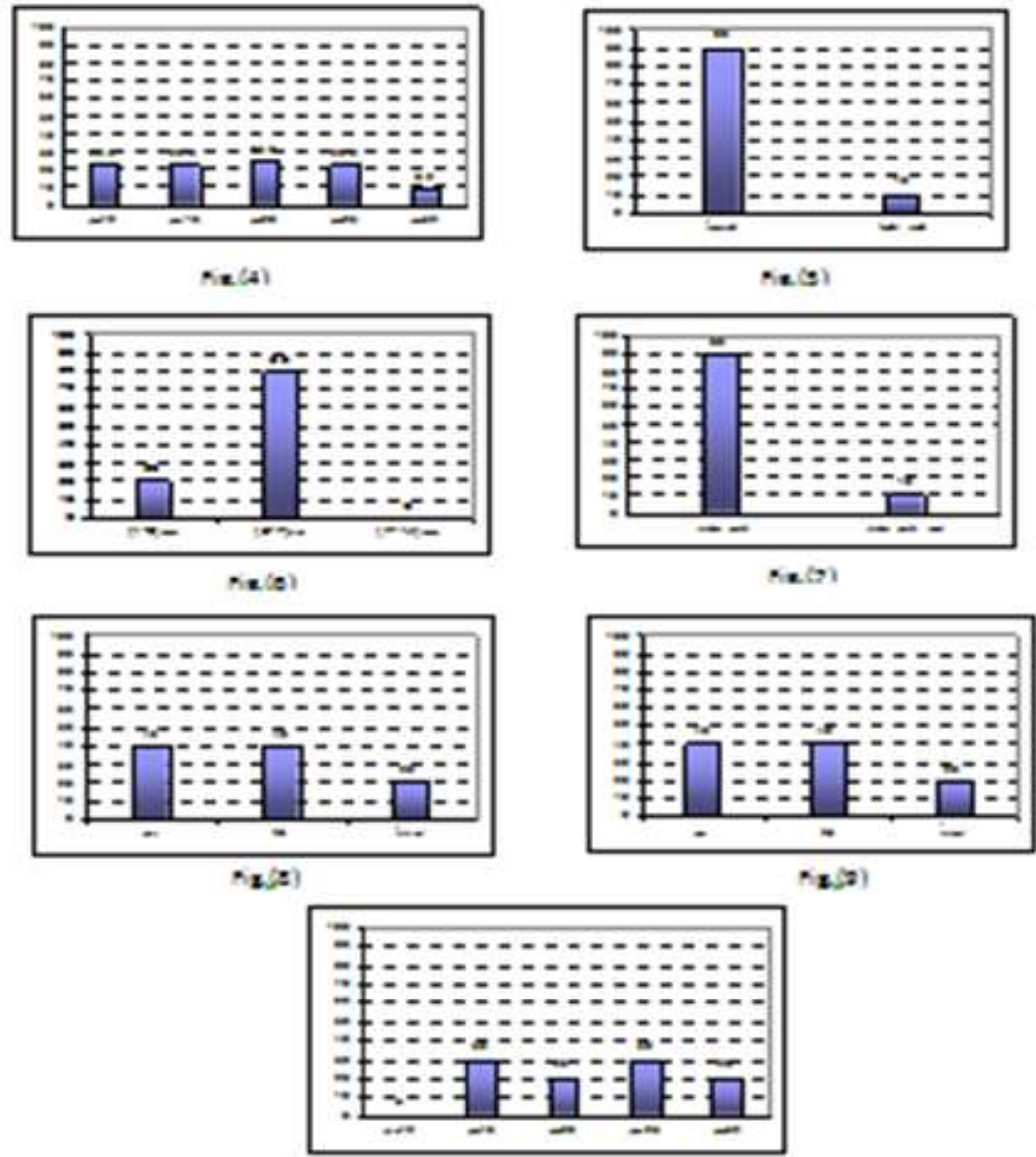

Ax $(20)$

Fig 11 The daily need for rebar steel

Fig 12. Weekly request resource form 
Available online at http://proceedings.sriweb.org
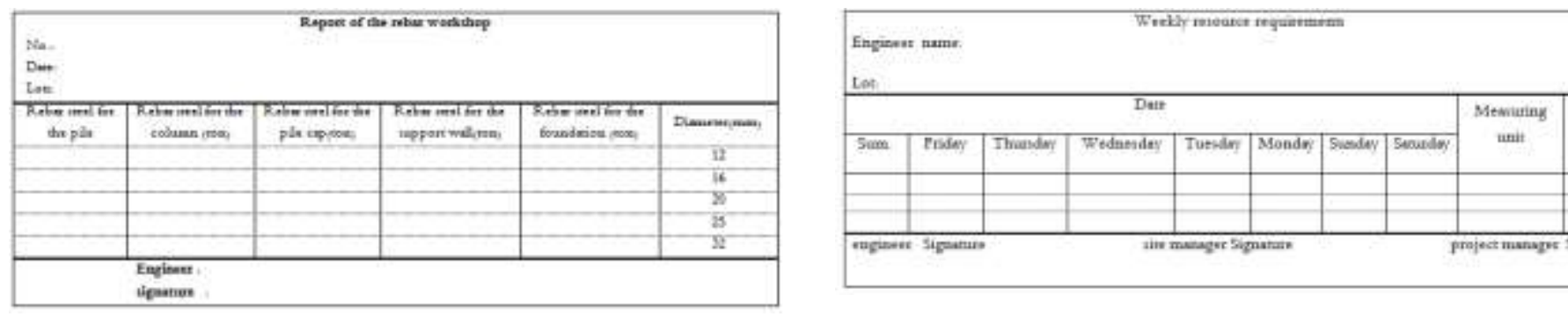

\section{Monitoring division}

The work of this Division is sensitive and important as it is related to project work progress within the planned schedule. Its work is based project work progress reports that are collected and compared with the planned schedule.

Analysis of reasons for the inability to achieve the planned completion ratio shows that $85 \%$ of delays (54\% lack of commitment to the time schedule+31\% lack of resources) are due to non-compliance to time schedule that was approved by senior management, as explained in table (4). Table (5) explains delays due to stops in project parts that have piles work.

The study and analysis of each part till 16/11/2005 as explained in table (6) and figure(13), the finish date for the whole project can be at (3/7/2007) with (437)days delay.

Table (7) and figure (14) represent the completion of one part of the project analysis model.

Table 4. Reasons for delays in project parts up to 6/11/2005

\begin{tabular}{|c|c|c|c|c|c|c|c|c|c|}
\hline $\begin{array}{l}\text { tos } \\
\text { No. }\end{array}$ & $\begin{array}{l}\text { Lack of } \\
\text { chaminmenz } \\
\text { to the } \\
\text { cienenitle }\end{array}$ & cendien & $\begin{array}{l}\text { Odtive } \\
\text { bolideys }\end{array}$ & $\begin{array}{l}\text { tack of } \\
\text { secuce }\end{array}$ & $\begin{array}{c}\text { Retemal } \\
\text { of } \\
\text { execuine }\end{array}$ & $\begin{array}{l}\text { Total } \\
\text { dolvy } \\
\text { durarion }\end{array}$ & $\begin{array}{c}\text { Timst } \\
\text { wreighe } \\
\text { foe the late }\end{array}$ & $\begin{array}{l}\text { Week } \\
\text { Duevion in } \\
\text { tha test }\end{array}$ & 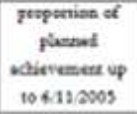 \\
\hline 1 & 30 & 70 & 3 & & & $n$ & 3075 & 24 & $10000 \%$ \\
\hline $2 t$ & 57 & & 3 & 4 & & 69 & 4.1356 & 93 & 92.2046 \\
\hline $2 n$ & 71 & & 3 & 2 & & 82 & 4736 & $: 00$ & $9220 \%$ \\
\hline$\pi t$ & 23 & & 2 & 38 & & 23 & 42016 & 202 & 50925 \\
\hline $3 R$ & 34 & & 3 & 44 & & 23 & 40215 & $n$ & $205+16$ \\
\hline it & 34 & & & 36 & & 49 & 4000 & 110 & 4925 \\
\hline $\mathbb{A R}$ & 6 & & & 56 & & 40 & 4.105 & 92 & $409 \%$ \\
\hline 3 & 23 & & 13 & 14 & & 42 & 3.044 & 213 & $100.60 \%$ \\
\hline 6 & 26 & & 21 & 7 & 30 & 79 & 63350 & (2) & 100.000 \\
\hline 7 & 94 & & 11 & 78 & & 243 & 22.2916 & 253 & $9259 \mathrm{~m}$ \\
\hline 8 & .5 & & , & 50 & 30 & 4 & 3976 & 294 & $53 \mathrm{cos}$ \\
\hline 9 & 22 & & 3 & 103 & & 135 & $950 \%$ & 213 & $925 \mathrm{~m}$ \\
\hline 20 & 39 & & 10 & 5 & & 34 & 6.646 & 267 & $52: 1646$ \\
\hline I1 & 221 & & & & & 221 & $10.95 \mathrm{~S}$ & 263 & 91.014 \\
\hline 12 & 67 & & 13 & 10 & & 90 & $4.90 \%$ & 120 & 100.0016 \\
\hline 15 & 26 & & 3 & & & 29 & 6.426 & 244 & 36500 \\
\hline$\Sigma$ & 33 & 4 & 7 & 31 & 4 & 93 & $100 \%$ & & \\
\hline
\end{tabular}

Fig 13. The percentage of reasons for the delay in project parts 


\section{Global Proceedings Repository \\ American Research Foundation}

ISSN 2476-017X

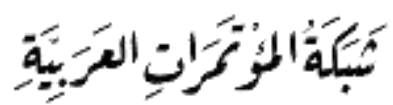

http://arab.kmshare.net/

Available online at http://proceedings.sriweb.org

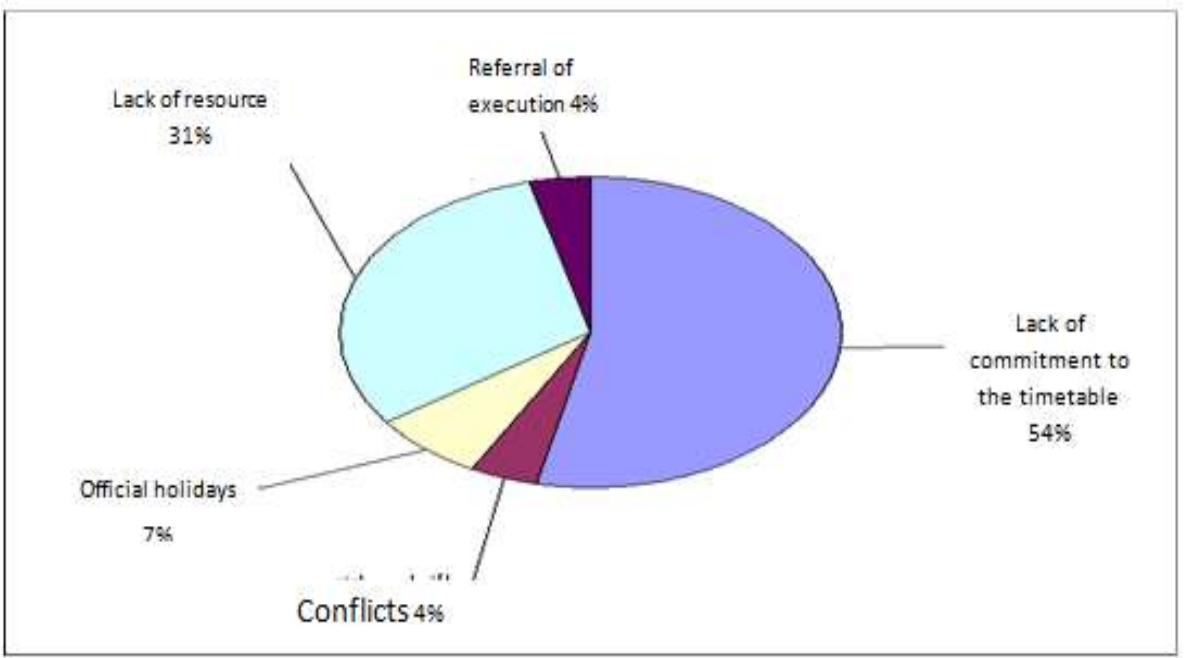

Table 5. Interruptions in work due to lack of piles excavators

Table 6. Actual and planned completion dates for projec

\begin{tabular}{|c|c|c|c|c|}
\hline \multicolumn{5}{|c|}{ 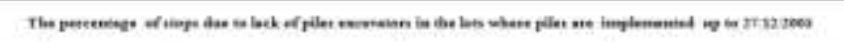 } \\
\hline Ler & gartiat don & 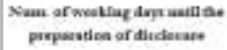 & 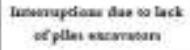 & 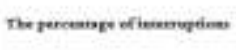 \\
\hline$x$ & $\sin e s 000$ & Iit & $\pi$ & B.sme \\
\hline sh & antritions & in & 48 & ac an \\
\hline ac & 1036.0000 & $\pi$ & $\mathbf{n}$ & " 214 \\
\hline an & 11.303000 & $\pi$ & $n$ & 4250 \\
\hline$n$ & Tentitos & " & $m$ & enthe \\
\hline \multicolumn{5}{|c|}{270} \\
\hline
\end{tabular}

\begin{tabular}{|c|c|c|}
\hline Lui Nu. & 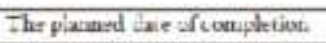 & 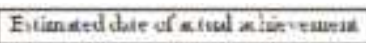 \\
\hline 1 & 31/103mะ & 215/70m, \\
\hline 21 & $15+2006$ & 29,9206 \\
\hline $2 \mathbb{R}$ & 2302006 & $199700 \mathrm{Nr}$ \\
\hline $3 I$ & $2.14+30 \times 6$ & 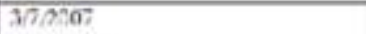 \\
\hline $\mathrm{g}$ & $21+30 \mathrm{ng}$ & 17,9007 \\
\hline $4 \mathrm{~L}$ & 236,2006 & $21,7 / 2005$ \\
\hline $4 \mathbb{R}$ & $200 \mathrm{c}+1 / 4$ & $71,7 / 2004$ \\
\hline 5 & $17 / 20 / 2007$ & 23,2006 \\
\hline 6 & $12 \pi 1000 \%$ & Ge $050 \%$ \\
\hline 7 & अब.30\% & $25,70 \times 0 \times 6$ \\
\hline 8 & $19 / 12004$ & 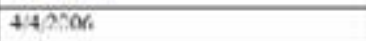 \\
\hline 9 & fit +7006 & 27,67006 \\
\hline 10 & $4,12,2003$ & $18,1 / 2006$ \\
\hline 11 & $18=7006$ & dons fur tet in ik- watk an it \\
\hline 12 & $12 \pi 1 / 300 \%$ & 21, 2007 \\
\hline 13 & $230 \operatorname{san} 6$ & $2 \operatorname{sen} x$ \\
\hline
\end{tabular}




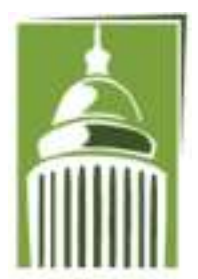

ARF

\section{Global Proceedings Repository \\ American Research Foundation}

ISSN 2476-017X

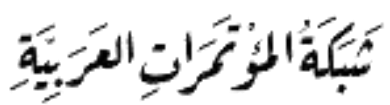

http://arab.kmshare.net/

Available online at http://proceedings.sriweb.org

Table 7. the completion of one of project parts of analysis model

\begin{tabular}{|c|c|c|c|c|c|}
\hline \multicolumn{6}{|c|}{ Leri } \\
\hline \multicolumn{6}{|c|}{ 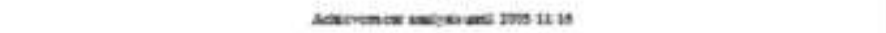 } \\
\hline 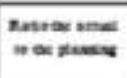 & sover & 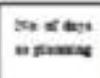 & 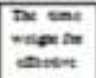 & 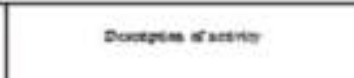 & $\begin{array}{l}\operatorname{sic} \alpha \\
\sin =0\end{array}$ \\
\hline $2 s t$ & 2 & 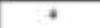 & tam & 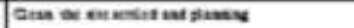 & 21 \\
\hline$i *$ & at & ii & $27+46$ & 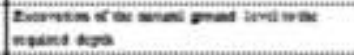 & 12 \\
\hline izi & $\pi$ & it & $z=$ & 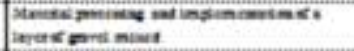 & 15 \\
\hline in & at & " & inim & 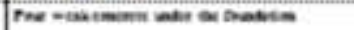 & t. \\
\hline $2 t$ & $\pi$ & $z$ & trits & 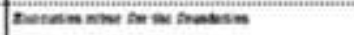 & $2 t$ \\
\hline int & i & * & $t=$ & 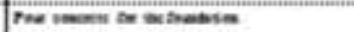 & 20 \\
\hline 80 & $=$ & $a$ & $i=n$ & 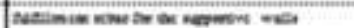 & if \\
\hline$\theta=0$ & " & $t$ & 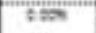 & 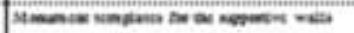 & $2 t$ \\
\hline$t=$ & $"$ & ; & $\theta=$ & 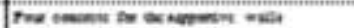 & 17 \\
\hline ise & "ln & is & काm & 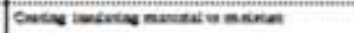 & 110 \\
\hline$z=$ & $z$ & (2) & $6=0$ & 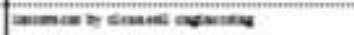 & 17 \\
\hline act & 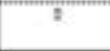 & 7 & $\tan$ & 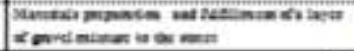 & 17 \\
\hline \multicolumn{6}{|c|}{ 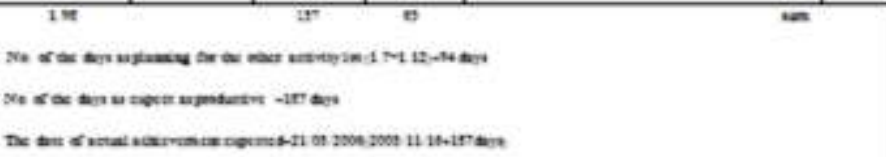 } \\
\hline \multirow{2}{*}{\multicolumn{6}{|c|}{$\cdot$ Note }} \\
\hline & & & & & \\
\hline \multicolumn{6}{|c|}{$\begin{array}{c}\text { The time weight for effective }=\text { (No. of days as planning for the activity/sum No .of days } \\
\text { as planning for the activities which there work in it(1.1-1.6)) }\end{array}$} \\
\hline \multicolumn{6}{|c|}{ "Ratio the actual to the planning $=$ No. of days as planning/No , actual days accumulated } \\
\hline \multirow{2}{*}{\multicolumn{6}{|c|}{$\begin{array}{l}\text {-sum No .of days as planning for the activitios which there work in it from } 1.1 \text { to } 1.6=63 \\
\text {-No. of the days as expect as productive }=\text { Ratio the actual to the planning } \times \text { No. of the } \\
\text { days as planning for the other activity lot }(1.7-1.12)\end{array}$}} \\
\hline & & & & & \\
\hline - & & & $=$ & & \\
\hline
\end{tabular}

Fig 14. percentage of completion of one of project parts analysis model

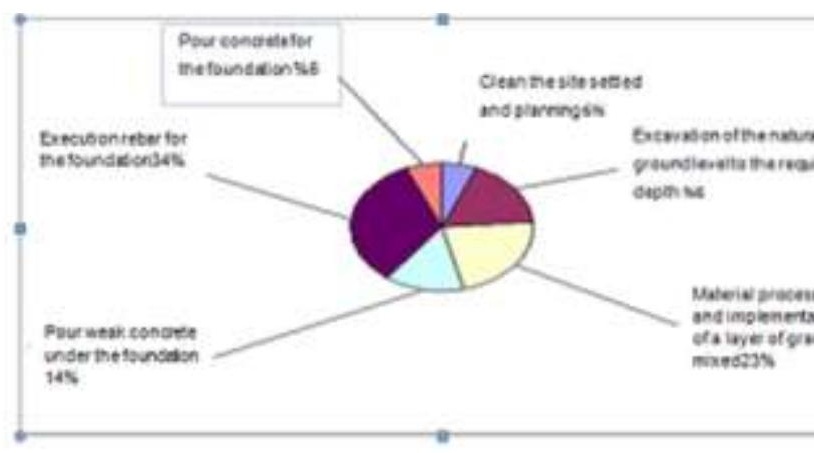




\section{Global Proceedings Repository American Research Foundation}

ISSN 2476-017X

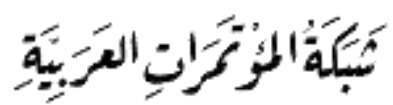

http://arab.kmshare.net/

Available online at http://proceedings.sriweb.org

When comparing the planned achievement ratios with that are actually achieved, the proportion of the deficit in the implementation of time schedule stand out clearly, as explained in table (8).

When calculating the deficit ratio for the period from 28/9/2005 until 02/12/2006 and representing it in a diagram as in Figure (15), three parts can be characterized, as follows:

1. The first part represents an increase in the deficit ratio which ends at $26.93 \%$.

2. The second part in which the curve flattens indicating the control of the deficit and stabilizes the rate between $(26.34-26.05 \%)$.

3. The third part, which has a decrease in the deficit ratio to $12.69 \%$, representing a recovery of nearly $14.24 \%$, a healthy sign of the increase in daily productivity rates which is explained in the table (9).

Table 8. comparison between planned and actual completion percentage

\begin{tabular}{|c|c|c|c|}
\hline beicepoen & Navaed poweronge & Actual & 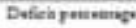 \\
\hline 1. plascoed Pencenaze of comipletioe without itops & 847 & \multirow{3}{*}{7421} & 10.9 \\
\hline 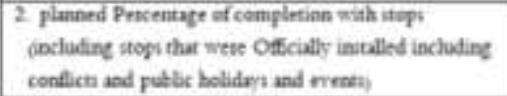 & BSTE & & 237 \\
\hline 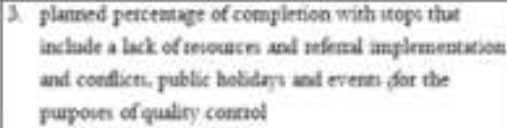 & 82.61 & & 8.4 \\
\hline
\end{tabular}

\section{*Note}

-Deficit ratio=The proportion of the planned-The proportion of the actual

-Disparity by deficit =previous deficit ratio-present deficit ratio
Table 9. Detection of deficit ratios in the implementation of time schedule

\begin{tabular}{|c|c|c|c|c|c|}
\hline Dait of atpon & $\begin{array}{l}\text { Propotson of } \\
\text { plaseed } \\
\text { schomremanat }\end{array}$ & $\begin{array}{l}\text { Thr paepection of } \\
\text {-mal schirventar }\end{array}$ & $\begin{array}{l}\text { Deficit } \\
\text { veno }\end{array}$ & $\begin{array}{l}\text { Deypenies of } \\
\text { Defacit atives }\end{array}$ & $\begin{array}{l}\text { Aurnimin } \\
\text { defiait 1 It }\end{array}$ \\
\hline DIBONSS & से & 3442 & 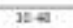 & & \\
\hline 05102005 & 4.27 & 55.7 & is & 800 & 7naveste the \\
\hline 12102006 & 49.59 & 36.72 & 10\% & 1.1 & Iascals the of \\
\hline $20: 02005$ & 307 & 3733 & $36 \pi$ & 21 & lacrene be \\
\hline N10.20es & 38.28 & 39.2 & 19.90 & 271 & lacences the \\
\hline 02113005 & 616 & 4025 & $22 \pi$ & 200 & locrum the \\
\hline $16113 \times 5$ & 7023 & 4.28 & $50 \mathrm{~m}$ & $7+\infty e^{2}$ & iscieast athe \\
\hline 211200 & 7491 & 7799 & 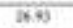 & 40 & lacasuse the \\
\hline 0.12306 & 711 & 504 & 25.60 & $0.5 t$ & inemnir th \\
\hline $16.1220 \mathrm{Ws}$ & 806 & 3426 & 534 & $-5 y$ & decrease da \\
\hline 28,123055 & 8215 & 3081 & $22 \pi$ & $-4(0)$ & increvis the \\
\hline 14012006 & 5034 & 6) & 1 (251 & $-2+1$ & deccenit the \\
\hline $2801,00 \%$ & (51 & 6732 & it 8 & -2.93 & dectene the \\
\hline 07022006 & 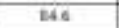 & 71.91 & 1200 & -4.10 & dectent the \\
\hline
\end{tabular}

Fig 15. deficit progression ratio between 5/9/2005 and 26/1/2006 


\section{Global Proceedings Repository \\ American Research Foundation}

ISSN 2476-017X

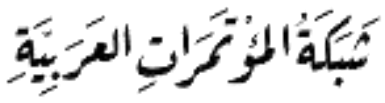

http://arab.kmshare.net/

Available online at http://proceedings.sriweb.org

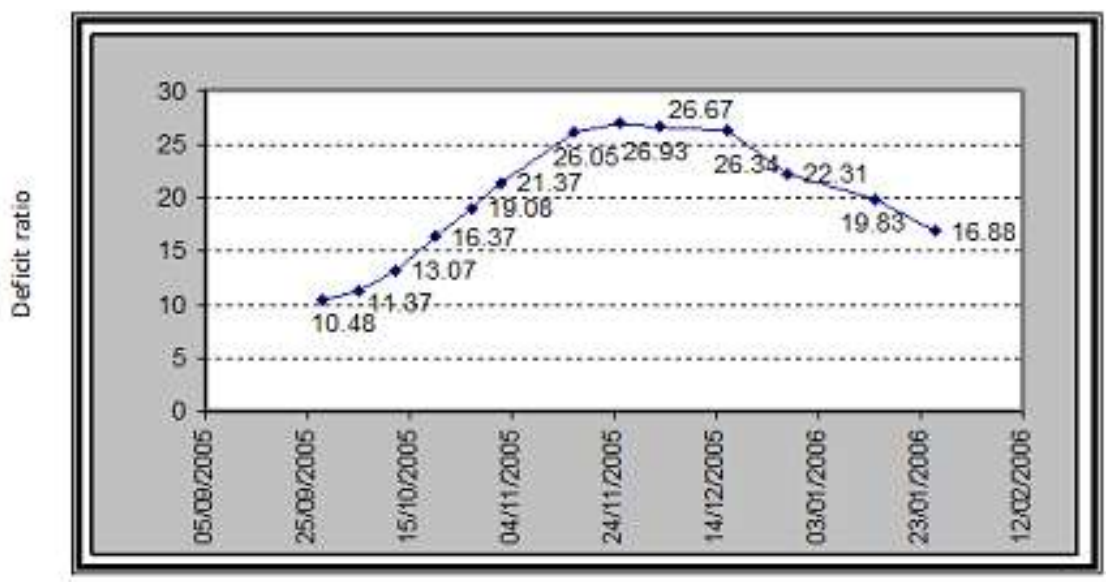

\section{Conclusion}

1- The proposed organizational structure of quality control department, which has been applied to a project (as case study) has proven its effectiveness by monitoring the decline in the deficit of the project completion rates.

2- In order to make the proposed organizational structure more effective, it is advised the existence of an operations research specialist or a construction management specialist in each division of the quality control department.

3- The problems and the solution that have been developed to solve them can be collected to develop an expert system for construction companies to facilitate the work in projects implementation. It can save time and expenses through the benefit of using the expert system in the engineering consulting when facing such problems in the future.

\section{References}

العظماوي ,فراس ابر اهيم كاظم, (نظام اداري متكامل للسيطرة النو عية الموقعية ) رسالة ماجستير رقسم هندسة البناء و [1] 2000, الانشاءات , الجامعة التكنولوجية

[2] Jerald L. Rounds M. ASCE and Naiyuan Chi, "Total Quality Management for Construction”, journal of construction and management, vol. 111 ,no. 2, 1985.

[3] Arditi, D. and Gunaydin, H. M. (1997). Total quality management in the construction process. International Journal of Project Management, 15(4), 235-243.

[4] Ferguson, H. and Clayton, L. (Eds), (1988). Quality in the Constructed Project: A Guideline for Owners, Designers and Constructors, 1, New York.

[5] Ledbetter, W. B. (1990). The quality performance management system: a blue print for implementation Construction Industry Institute, Austin.

[6] Gunaydin, H. M. (1995). TQM in the Construction Industry. (Masters' Thesis), Illinois Institute of Technology: Chicago.

[7] Burati, J. L. et al., (1992). Quality management organizations and techniques. Journal of Construction Engineering and Management, 118(1), 112-128.

[8] H. Mallawaarachchi \& S. Senaratne," Importance of Quality for Construction Project Success", international conference on structural Engineering and construction management, Kandy, Srilanka, December 2015. 


\section{Global Proceedings Repository \\ American Research Foundation}

ISSN 2476-017X

Available online at http://proceedings.sriweb.org

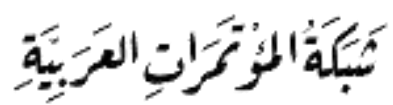

http://arab.kmshare.net/ 